\title{
Examination of the Attitudes of Adanaspor's and Adana Demirspor's Supporters Relevant to Fanaticism
}

\author{
Murat ATASOY ${ }^{1}$ \\ ${ }^{1}$ School of Physical Education and Sports, Ahi Evran University, Kırşehir, Turkey \\ Correspondence: Murat Atasoy, School of Physical Education and Sports, Ahi Evran University, Kırşehir, \\ Turkey. E-mail: muratatasoy40@gmail.com
}

Received: October 25, 2018

Accepted: November 22, 2018 Online Published: December 30, 2018

doi:10.5539/jel.v8n1p158

URL: https://doi.org/10.5539/jel.v8n1p158

\begin{abstract}
The purpose of this research is to examine the behaviors of Adanaspor's and Adana Demirspor's supporters relevant to fanaticism, and to reveal factors causing partisanship and identification levels of partisanship with psycho-social aspects in the context of football fanaticism and supporter identity. The model of this study is screening. 160 supporters in total, as being 80 Adanaspor's supporters and 80 Adana Demirspor's supporters, are constituting the study group. In this study, Football Supporters Fanaticism Scale developed by Taşmektepli et al. (2014) has been used as data collection tool. The analysis of data has been performed by SPSS 22 packaged software. First, percentage and frequency analysis have been performed for age, educational background and profession information of each participant, and distribution (Sample K-S) and homogeneity (ANOVA) analyses have been performed in the determination of difference. As per the results of the research, while they are definitely agreeing with the judgments of "I get very angry at the comments of the speaker during live broadcasts which are against the team", "I go to the stadium for watching my team's matches", "I go to the match with clothing and materials indicating the symbols of my team", "I join all the cheering at the stadium", "I try to make the individuals or children - who don't support a team - the supporters of my team", they are definitely not agreeing with the judgments of "I may throw foreign bodies to field when I get angry during the match", "My team should try all the means including exceptions in order to win the match", "I may sometimes enter the field if the game has gone off the rails". The comparison of the teams that the supporters support and of their fanaticism attitudes has been made, and significant difference has been determined in favor of Adanaspor in the judgments of "I get very angry at the comments of the speaker during live broadcasts which are against the team" and "I go to the match with clothing and materials indicating the symbols of my team".
\end{abstract}

Keywords: supporter, fanaticism, attitude, sports

\section{Introduction}

Since the early periods of history, the mankind has often been the supporter of the values system that he is adhered to, of his ethnic origins, or of competing athletes like in the Ancient Olympics (Ylldiran, 1996). The fact of partisanship is showing up most specifically in the arena of sports. And a systematic partisanship fact has started in England along with industrialization, and has developed within the schools and factories. Through direction of the factory owners in order to prevent the workers from being organized as speaking of the working conditions and problems at the factory, weaving workers from Manchester had found M. United, workers of Kingdom's Weapon Factory had found Arsenal, port workers had found Liverpool, and coal workers had found the Nottingham club. It had been ensured for the workers to gather around their own factory teams, and their sense of belonging for the corporation had been reinforced in the direction of supporter identity (Fişek, 1985).

The developments in mass media such as internet and printed and visual media have increased the interest of public in sports, and thus sports has ceased to only be some body movements or simple competitions, and has became a tool of excitement trailing a wide audience. In this respect, sports partisanship is consisting another form of leisure time behavior of today's society. In this sense, one of the most common criticism against sports partisanship is that partisanship is a passive activity, and that it is not similar to active involvement in sports. Many researchers have considered partisanship and sports adoration equal with laziness. In fact, activity cannot be expected from all the people. Partisanship enables some segments of the society such as sick, elder, disabled individuals to watch and participate in the events without the requirement of physical ability. While active 
participation in sports is necessitating factors such as sportive equipments, facilities and competitors, these are being required at the lowest level in being a sports fan or supporter (Başer, 1985).

Most of the people are assessing themselves as sports supporters, and being interested in sports events. Being defined as a sports fan or supporter has different meanings among individuals. For some, the supporter identity can be a very important factor in the determination of social status. In addition, partisanship increases self-respect and prestige, and also provides social gains such as the development of senses of social solidarity and friendship. Factors such as family, social sphere, friends and relatives or such as being near a strong, winning, popular team are able to be effective in being a supporter. While becoming a supporter, the people don't often decide through thinking over. The team is supported, and it goes along in that manner. But a preference made without thinking in detail turns to a loyalty which continues along the life, and this has an irrational aspect. Because in this context, the general opinion on what the rational behavior is is being specified as re-establishing the reliance and trust with another individual or corporation when an individual or corporation one relies on disappoints him. However, the partisanship identity often doesn't cause such a behavior. To the contrary, even in case of a severe defeat of the team, the supporter often doesn't change his team, and continues to maintain his hope, trust and excitement (Horak et al., 2001).

Football has systematically and gradually changed its structuring in socio-economic, financial, economic and organizational sense, and transformed to industrial football. The professionalism, that is the highest level football has reached in industrial sense, has created its own economic and legal values. Football is a sports branch that has became mass attraction center in the whole world (Zelyurt, 2013). The supporter is the consumer emotionally adhered to sports. But in practice, it is also possible to be a supporter and not being an audience member or vice versa. It is possible not to watch the matches of the supported clubs despite being obliged to specify the supporter identity for not being detached from mutual or group relationships and for no drifting apart from the conversation. Moreover, matches may also be watched only due to liking it without being a supporter (Hünerli, 2011).

Today, many people are following-up the sports events through media, spending their leisure time by doing physical exercise, watching the sports events on-site, and even adopting sports as a profession for earning living. Despite all these, it can be said that especially watching football is the most common activity relevant to sports (Sen, 2013).

In recent years, the incidences of violence arising during sports competition and especially during football competitions are creating a negative effect on the universal values and uniting features of sports such as love, peace and brotherhood. One of the most significant effects of the factor of violence in sports is lack of sufficient internalization of sports. Lack of making a distinction in between excitement and tension, and preference of result instead of performance target are causing violence. In sports community, in which the people are focused only on victory, and in which the gentlemanliness and moral values are degenerated, the manner of expression is showing up as aggression and violence (Duyar, 2011).

It is drawing attention why the people allocate time to watch a sportive competition from TV, why they travel for hours in order to watch a competition on-site, or why the fanatic supporters are painting themselves with the colors of their team. While such individuals are sometimes remaining at the level of audience, they are sometimes able to show violence in order to preserve the values of their team. In this respect, determination of psycho-social factors of people's behaviors relevant to partisanship will be able to provide contribution in terms of defining the borders of supporter behavior.

\section{Method}

\subsection{Research Model}

The model of this study is screening. Screening models is a research approach intending to portray a past or current status as is (Büyüköztürk, 2009).

\subsection{Universe and Sample}

While individuals residing at the province of Adana and supporting any sports team are constituting the research's universe, 160 supporters in total-as being 80 Adanaspor supporters and 80 Adana Demirspor supporters - accepting to participate in the research and residing at the province of Adana are constituting the research's sample. $50 \%$ of the supporters participating in the research are supporters of Adanaspor, and $50 \%$ of them are supporters of Adana Demirspor. 


\subsection{Data Collection Tool}

In this study, Football Supporters Fanaticism Scale developed by Taşmektepli et al. (2014) has been used as data collection tool.

\subsection{Analysis of Data}

The analysis of data has been performed by SPSS 22 packaged software. First, frequency analysis has been performed for age, educational background and profession information of each participant, and distribution (Sample K-S) and homogeneity (ANOVA) analyses have been performed in the determination of difference. In the statistical significance calculations of the values, being smaller than 0.05 - which is deemed as the limit value - has shown that the distribution of examined factors is not normal.

\section{Results}

Table 1. Percentages and frequencies of the teams supported by the supporters participating in the research

\begin{tabular}{lll}
\hline Team & $\mathbf{N}$ & $\mathbf{\%}$ \\
\hline Adanaspor & 80 & 50.0 \\
Adana Demir Spor & 80 & 50.0 \\
Total & 160 & 100.0 \\
\hline
\end{tabular}

$50 \%$ of the supporters are supporters of Adanaspor, and 50\% of them are supporters of Adana Demirspor.

Table 2. Percentages and frequencies of the educational background of the supporters participating in the research

\begin{tabular}{lll}
\hline Educational Background & N & \% \\
\hline Primary School & 24 & 15.0 \\
Secondary School & 28 & 17.5 \\
High School & 32 & 20.0 \\
Associate's Degree & 12 & 7.5 \\
Graduate Degree & 61 & 38.1 \\
Post Graduate & 2 & 1.2 \\
Doctor's Degree & 1 & 0.7 \\
Total & 160 & 100 \\
\hline
\end{tabular}

$15 \%$ of the supporters are primary school graduates, $17.5 \%$ of them are secondary school graduates, $20 \%$ of them are high school graduates, $7.5 \%$ of them have associate's degree, $38.1 \%$ of them are university graduates, $1.2 \%$ of them are post graduates, and $0.7 \%$ of them have doctor's degree.

Table 3. Percentages and frequencies of the professional background of the supporters participating in the research

\begin{tabular}{lll}
\hline Profession & $\mathbf{N}$ & $\mathbf{\%}$ \\
\hline Student & 88 & 55.0 \\
Unemployed & 3 & 1.9 \\
Retired & 10 & 6.2 \\
Worker & 28 & 17.5 \\
Self-employed & 8 & 5.0 \\
Government officer & 12 & 7.5 \\
Craftsman & 11 & 6.9 \\
Total & 160 & 100 \\
\hline
\end{tabular}

$55 \%$ of the supporters are students, $1.9 \%$ of them are unemployed, $6.2 \%$ of them are retired, $17.5 \%$ of them are workers, $5 \%$ of them are self-employed, $7.5 \%$ of them are government officers, and $6.9 \%$ of them are craftsmen. 
Table 4. Results of partisanship attitudes of supporters participating in the research

\begin{tabular}{|c|c|c|c|c|c|c|c|c|c|}
\hline \multirow[t]{2}{*}{ ATTITUDE } & \multicolumn{2}{|c|}{$\begin{array}{l}\text { I definitely } \\
\text { don't agree }\end{array}$} & \multicolumn{2}{|c|}{$\begin{array}{l}\text { I don’t } \\
\text { agree }\end{array}$} & \multicolumn{2}{|c|}{ I do agree } & \multicolumn{2}{|c|}{$\begin{array}{l}\text { I definitely } \\
\text { agree }\end{array}$} & \multirow[t]{2}{*}{$\mathrm{X} \pm \mathrm{ss}$} \\
\hline & $\mathrm{N}$ & $\%$ & $\mathrm{~N}$ & $\%$ & $\mathrm{~N}$ & $\%$ & $\mathrm{~N}$ & $\%$ & \\
\hline $\begin{array}{l}\text { I get very angry at the comments of the speaker against the } \\
\text { team during live broadcast }\end{array}$ & - & - & 3 & 1.9 & 11 & 6.9 & 146 & 91.2 & $3.89 \pm .36$ \\
\hline I got to stadium for watching the matches of my team & 1 & .6 & 21 & 13.1 & 35 & 21.9 & 103 & 64.4 & $3.50 \pm .74$ \\
\hline $\begin{array}{l}\text { I go to match with the clothing and materials indicating the } \\
\text { symbols of my team }\end{array}$ & - & - & 37 & 23.1 & 54 & 33.8 & 69 & 43.1 & $3.20 \pm .79$ \\
\hline I accompany all the cheering at the stadium & 1 & .6 & 48 & 30.0 & 47 & 29.4 & 64 & 40.0 & $3.08 \pm .84$ \\
\hline $\begin{array}{l}\text { I may throw foreign objects to the field when I get angry } \\
\text { during the match }\end{array}$ & 87 & 54.4 & 58 & 36.2 & 5 & 3.1 & 10 & 6.2 & $1.61 \pm .82$ \\
\hline Often I don't see the goal due to dealing with the tribunes & 1 & .6 & 43 & 26.9 & 108 & 67.5 & 8 & 5.0 & $2.76 \pm .54$ \\
\hline $\begin{array}{l}\text { My team should try all the means including exceptions in } \\
\text { order to win the competition }\end{array}$ & 102 & 63.8 & 35 & 21.9 & 21 & 13.1 & 2 & 1.2 & $1.51 \pm .76$ \\
\hline $\begin{array}{l}\text { Often I make negative cheering from the tribune against the } \\
\text { players of the opposing team or referee }\end{array}$ & 39 & 24.4 & 35 & 21.9 & 59 & 36.9 & 27 & 16.9 & $2.46 \pm 1.03$ \\
\hline $\begin{array}{l}\text { I take naturally the physical force against the supporters of } \\
\text { opposing team }\end{array}$ & 56 & 35.0 & 38 & 23.8 & 60 & 37.5 & 6 & 3.8 & $2.10 \pm .93$ \\
\hline $\begin{array}{l}\text { I try to make the individuals or children-who don't support a } \\
\text { team - to be supporters of my team }\end{array}$ & 1 & .6 & 5 & 3.1 & 64 & 4.0 & 90 & 56.2 & $3.51 \pm .59$ \\
\hline $\begin{array}{l}\text { If I see the audience of the opposing team on the street, I try } \\
\text { hard for not attacking him }\end{array}$ & 59 & 36.9 & 62 & 38.8 & 12 & 7.5 & 27 & 16.9 & $2.04 \pm 1.06$ \\
\hline $\begin{array}{l}\text { In case of fight with the audience of opposing team, I involve } \\
\text { in the fight without hesitation }\end{array}$ & 53 & 33.1 & 57 & 35.6 & 21 & 13.1 & 29 & 18.1 & $2.16 \pm 1.08$ \\
\hline $\begin{array}{l}\text { If the match has gone of the rails, I may enter the field } \\
\text { without hesitation }\end{array}$ & 74 & 46.2 & 6 & 41.2 & 19 & 11.9 & 1 & .6 & $1.66 \pm .70$ \\
\hline
\end{tabular}

According to Table 4, while the supporters are definitely agreeing with the judgments of "I get very angry at the comments of the speaker during live broadcasts which are against the team", "I go to the stadium for watching my team's matches", "I go to the match with clothing and materials indicating the symbols of my team", "I join all the cheering at the stadium", "I try to make the individuals or children -who don't support a team-the supporters of my team", they are definitely not agreeing with the judgments of "I may throw foreign bodies to field when I get angry during the match", "My team should try all the means including exceptions in order to win the match", "I may sometimes enter the field if the game has gone off the rails".

Table 5. Comparison of team that the supporters-participating in the research—support, and their partisanship attitudes

\begin{tabular}{|c|c|c|c|c|c|c|}
\hline Attitude & Team & $\mathbf{N}$ & $\mathbf{X}$ & Ss & Mean Rank & $\mathbf{p}$ \\
\hline \multirow{2}{*}{$\begin{array}{l}\text { I get very angry at the comments of the speaker against the team } \\
\text { during live broadcast }\end{array}$} & Adanaspor & 80 & 3.96 & .19 & 84.56 & \multirow[t]{2}{*}{.24} \\
\hline & Adana Demir Spor & 80 & 3.82 & .47 & 76.44 & \\
\hline \multirow[t]{2}{*}{ I got to stadium for watching the matches of my team } & Adanaspor & 80 & 3.58 & .68 & 85.15 & \multirow[t]{2}{*}{.135} \\
\hline & Adana Demir Spor & 80 & 3.41 & .79 & 75.85 & \\
\hline \multirow{2}{*}{$\begin{array}{l}\text { I go to match with the clothing and materials indicating the } \\
\text { symbols of my team }\end{array}$} & Adanaspor & 80 & 3.32 & .77 & 87.49 & \multirow[t]{2}{*}{.41} \\
\hline & Adana Demir Spor & 80 & 3.07 & .79 & 73.51 & \\
\hline \multirow[t]{2}{*}{ I accompany all the cheering at the stadium } & Adanaspor & 80 & 3.21 & .83 & 86.89 & \multirow[t]{2}{*}{63} \\
\hline & Adana Demir Spor & 80 & 2.96 & .84 & 74.11 & \\
\hline \multirow{2}{*}{$\begin{array}{l}\text { I may throw foreign objects to the field when I get angry during } \\
\text { the match }\end{array}$} & Adanaspor & 80 & 1.60 & .88 & 78.01 & \multirow[t]{2}{*}{.445} \\
\hline & Adana Demir Spor & 80 & 1.62 & .76 & 82.99 & \\
\hline \multirow[t]{2}{*}{ Often I don't see the goal due to dealing with the tribunes } & Adanaspor & 80 & 2.77 & .50 & 80.86 & \multirow[t]{2}{*}{.906} \\
\hline & Adana Demir Spor & 80 & 2.76 & .57 & 80.14 & \\
\hline \multirow{2}{*}{$\begin{array}{l}\text { My team should try all the means including exceptions in order to } \\
\text { win the competition }\end{array}$} & Adanaspor & 80 & 1.45 & .69 & 77.77 & \multirow[t]{2}{*}{.382} \\
\hline & Adana Demir Spor & 80 & 1.58 & .83 & 83.23 & \\
\hline \multirow{2}{*}{$\begin{array}{l}\text { Often I make negative cheering from the tribune against the } \\
\text { players of the opposing team or referee }\end{array}$} & Adanaspor & 80 & 2.52 & 1.03 & 83.05 & \multirow[t]{2}{*}{.468} \\
\hline & Adana Demir Spor & 80 & 2.40 & 1.05 & 77.95 & \\
\hline \multirow{2}{*}{$\begin{array}{l}\text { I take naturally the physical force against the supporters of } \\
\text { opposing team }\end{array}$} & Adanaspor & 80 & 2.18 & .94 & 84.74 & \multirow[t]{2}{*}{.220} \\
\hline & Adana Demir Spor & 80 & 2.01 & .92 & 76.26 & \\
\hline \multirow{2}{*}{$\begin{array}{l}\text { I try to make the individuals or children-who don't support a } \\
\text { team - to be supporters of my team }\end{array}$} & Adanaspor & 80 & 3.58 & .49 & 83.74 & \multirow[t]{2}{*}{.310} \\
\hline & Adana Demir Spor & 80 & 3.45 & .67 & 77.26 & \\
\hline \multirow{4}{*}{$\begin{array}{l}\text { If I see the audience of the opposing team on the street, I try hard } \\
\text { for not attacking him } \\
\text { In case of fight with the audience of opposing team, I involve in } \\
\text { the fight without hesitation }\end{array}$} & Adanaspor & 80 & 2.11 & 1.07 & 83.45 & \multirow[t]{2}{*}{.392} \\
\hline & Adana Demir Spor & 80 & 1.97 & 1.04 & 77.55 & \\
\hline & Adanaspor & 80 & 2.18 & 1.06 & 81.89 & \multirow[t]{2}{*}{.691} \\
\hline & Adana Demir Spor & 80 & 2.13 & 1.09 & 79.11 & \\
\hline
\end{tabular}




\begin{tabular}{llllll} 
If the match has gone of the rails, I may enter the field without & Adanaspor & 80 & 1.66 & .67 & 80.78 \\
hesitation & Adana Demir Spor & 80 & 1.67 & .74 & 80.22 \\
\hline
\end{tabular}

In table 5, the comparison of the teams that the supporters - participating in the research - support and of their fanaticism attitudes has been made, and significant difference has been determined in favor of Adanaspor in the judgment of "I get very angry at the comments of the speaker during live broadcasts which are against the team" $(X=3.96 \pm .19)$ and in the judgment of "I go to the match with clothing and materials indicating the symbols of my team" $(X=3.32 \pm .77)$.

\section{Discussion}

In this study, the behaviors of Adanaspor's and Adana Demirspor's supporters relevant to fanaticism have been examined, and factors causing partisanship and identification levels of partisanship with psycho-social aspects in the context of football fanaticism and supporter identity have been revealed.

When the partisanship attitudes of the supporters are considered, while they are definitely agreeing with the judgments of "I get very angry at the comments of the speaker during live broadcasts which are against the team", "I go to the stadium for watching my team's matches", "I go to the match with clothing and materials indicating the symbols of my team", "I join all the cheering at the stadium", "I try to make the individuals or children -who don't support a team-the supporters of my team", they are definitely not agreeing with the judgments of "I may throw foreign bodies to field when I get angry during the match", "My team should try all the means including exceptions in order to win the match", "I may sometimes enter the field if the game has gone off the rails".

The comparison of the teams that the supporters support and of their fanaticism attitudes has been made, and significant difference has been determined in favor of Adanaspor in the judgment of "I get very angry at the comments of the speaker during live broadcasts which are against the team" $(X=3.96 \pm .19)$ and in the judgment of "I go to the match with clothing and materials indicating the symbols of my team" ( $X=3.32 \pm .77)$.

In the research realized by Yamen (1999), it has again been found that the partisanship ages of the supporters is concentrating at age 14 and below at a rate of $87.4 \%$. These findings are similar to our findings. In children, this period is being called the latency period. The children of this age are able to seek a more acceptable identification model along with socialization besides the close identification factors such as mother, father and aunt. Along with the socialization process, the children are able to identify themselves with successful and popular team, their players, colors and emblems. In the study realized by Gençay and Karaküçük (2006), the concentration of partisanship age on the latency period of development has been related to these reasons. And in the study realized by Öztürk et al. (1997), it has been found that the "success of players" $(22.3 \%)$ and "popularity of the team" (18.5\%) are the factors having he highest effect. And Yamen (1999) has listed most significant factors in partisanship of university students as "success of the supported team" $(31.6 \%)$ and "popularity" (20\%).

Wann and Branscombe have classified the supporters as "die-hard supporters" and "fair-weather supporters". The ones in the first group continue to be loyal to their team no matter what even in case of years of unsuccess. The ones in the second group are the ones that approach the team when it is successful, and that take the advantage of the team's success. Wann and Branscombe allege that these two processes may explain the fluctuation of number of audience in time, and that decrease in number of audience in a bad season of a team is due to strong tendency of supporters - having low level of identification — to cut their relation with unsuccess.

Uhler has informed that men has more sports knowledge compared to women, that they interested in sports more, and that they allocate more time for watching matches on TV and for having discussions on sports, and that the women follow-up the sportive events on TV due to socialization with their families and friends (Katırc1, 2009).

Duyar (2011), Yıldız et al. (2007), Gümüş et al. (2014) have determined by their studies that individuals of low income level have a higher aggression and violence level, and Çağlayan and Fişekçioğlu (2014), Kabak (2009), Bar (2012), Şanlı (2014), Kaplan (2011) have determined by their studies that there is no relation in between monthly income and aggression and violence. Afyon and Metin (2014) have determined by their studies made on the football players that the individuals allocating more time to sports have higher aggression and violence levels.

\section{References}

Afyon, M., \& Metin, S. C. (2014). Muğla süper amatör ligindeki futbolcuların saldırganlık düzeylerinin incelenmesi. Spor ve Performans Araştırmaları Dergisi, 6(1), 5-11. https://doi.org/10.17155/spd.05537 
Bar, M. (2012). Futbol seyircisini şiddete yönelten faktörlerin değerlendirilmesi. Selçuk Üniversitesi SBE Yüksek Lisans Tezi, Konya.

Başer, E. (1985). Uygulamalı spor psikolojisi performans sporunda psikolojinin rolü. Ankara: Milli eğitim Gençlik ve Spor Bakanlığı Yayımlar Dairesi Başkanlığı.

Büyüköztürk, Ş. (2009). Sosyal bilimler için veri analizi el kitabı. Ankara: Pegem A Yayıncılık.

Çağlayan, M., \& Fişekçioğlu, D. (2009). Üniversite öğrencilerinin rekreasyonel etkinliklere katılımlarında engel oluşturabilecek faktörlerin belirlenmesi. Uluslararası Insan Bilimleri Dergisi, 6(1), 838-846.

Duyar, D. (2011). Futbol seyircisinde saldirganlık davranışlarının incelenmesi. Selçuk Üniversitesi SBE Yüksek Lisans Tezi, Konya.

Duyar, Ö. G. (2011). Futbolun dayanılmaz çekiciliği, büyülenen taraftar portresi. Fanatizm ve Beşiktaş. Mini Folklor, 22, 85 .

Fişek, K. (1985). 100 Soruda Türkiye spor tarihi. İstanbul: Gerçek Yayınevi.

Gençay, S., Karaküçük, S. (2006). Üniversite öğrencilerinin spor taraftarlığı ile ilgili davranışları üzerine bir araştırma. Gazi Beden ve Spor bilimleri Dergisi, 11.

Gümüş, T. (2014). Kendini kabul düzeyleri farklı lise öğrencilerinin bazı değişkenlere göre saldırganlı düzeyleri. Yüksek lisans tezi, Hacettepe Üniversitesi, Ankara.

Horak, R., Retter, W., \& Bora, T. (2001). Futbol ve kültürü, takımlar, taraftarlar, endüstri, efsaneler (3. Bask1). İstanbul: İletişim Yayınları.

Hünerli, S. (2011). Türkiye'de futbol iktidarı ve fanatizmin karikatürlerde yansıması. Sanat Dergisi, 19, 97-108.

Kabak, Ç. (2009). Üniversite öğrencilerinde saldırganlı̆̆ yordayan bazı değişkenler. Yüksek lisans tezi, Gazi Üniversitesi, Ankara.

Kaplan, Z. (2011). Lise öğrencilerinde öfke ve saldırganlık. Ç.Ü. Sosyal Bilimler Enstitüsü Dergisi, 17(3), 277-294.

Katırcı, H. (2009). Türkiye'de futbol kulübü-taraftar iletişimi. Beden Eğitimi ve Spor Bilimleri Dergisi, 4(1), $41-50$.

Mutlu, K. (1991). Sporda anarşi ve şiddet, spor ahlakı ve spor felsefesine yeni yaklaşımlar. Yayına Hazırlayan: A. Erdemli, İstanbul.

Öztürk, F., Şahin, M., Zülkadiroğlu, Z., \& İnce, M. (1997). Üniversite gençliğinin futbolda takım tutma durumlarının araştıılması. (Ed. Şefik Tiryaki) 1. Uluslararası Spor Psikolojisi Bildirileri. Ankara: Bağırgan Yayınevi.

Şanl, S. (2014). Futbol müsabakalarında olaylarda yer alan seyircilerin saldırganlık düzeylerinin belirlenmesi. Doktora Tezi, Gazi Üniversitesi, Ankara.

SEN, H. (2013). Futbolun değişen yapısı üzerine sosyolojik bir analiz. Sosyal Bilimler Dergisi, 1, 88-105.

Taşmektepli, M. Y., Çankaya, S., \& Tunç, T. (2014). Futbol taraftarı fanatiklik ölçeği. Spor ve Performans Araştırmaları Dergisi, 6(1), 41-49. https://doi.org/10.17155/spd.73408

Yamen, E. (1999). Sporda taraftarlığın farklı toplumsal gruplara göre karşılaştırmalı olarak incelenmesi (Sivas örneklemi). Cumhuriyet Üniversitesi SBE Yüksek Lisans Tezi, Sivas.

Yıldıran, İ. (1996). Sporda Fair Play kavramının tarihsel boyutları. Hacettepe Üniversitesi Spor Bilimleri 2. Ulusal Kongresi Bildirileri, Kasım, Yayın No: 3, İstanbul, s. 174-179.

Yıldız, Y. (2007). Hukuk ve kültür ilişkisi çerçevesinde spor kültürünün oluşturulması. Celal Bayar Üniversitesi Sosyal Bilimler Dergisi, 2, 21-42

Zelyurt, M. K. (2013). Dünyanın çeşitli ülkelerinde etnik gerilimler bağlamında futbol. İnsan ve Toplum Bilimleri Araştırmaları Dergisi, 2(2), 197-222.

\section{Copyrights}

Copyright for this article is retained by the author, with first publication rights granted to the journal.

This is an open-access article distributed under the terms and conditions of the Creative Commons Attribution license (http://creativecommons.org/licenses/by/4.0/). 